\title{
EFFECTS OF MANAGEMENT PRACTICES ON GRASSLAND BIRDS:
}

FIELD SPARROW

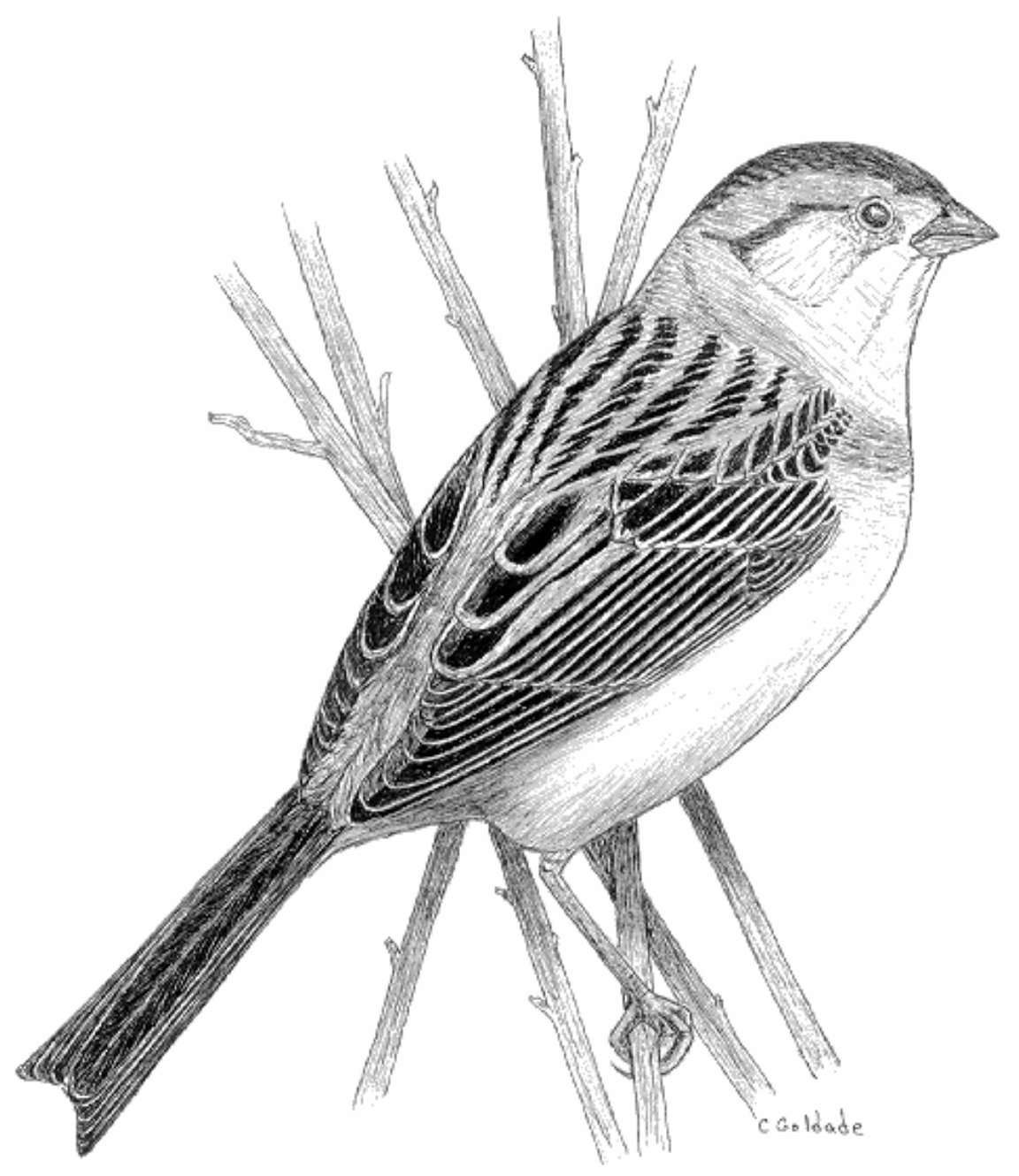

Grasslands Ecosystem Initiative

Northern Prairie Wildlife Research Center

U.S. Geological Survey

Jamestown, North Dakota 58401 
This report is one in a series of literature syntheses on North American grassland birds. The need for these reports was identified by the Prairie Pothole Joint Venture (PPJV), a part of the North American Waterfowl Management Plan. The PPJV recently adopted a new goal, to stabilize or increase populations of declining grassland- and wetland-associated wildlife species in the Prairie Pothole Region. To further that objective, it is essential to understand the habitat needs of birds other than waterfowl, and how management practices affect their habitats. The focus of these reports is on management of breeding habitat, particularly in the northern Great Plains.

Suggested citation:

Dechant, J. A., M. L. Sondreal, D. H. Johnson, L. D. Igl, C. M. Goldade, B. D. Parkin, and B. R. Euliss. 1999 (revised 2002). Effects of management practices on grassland birds: Field Sparrow. Northern Prairie Wildlife Research Center, Jamestown, ND. 20 pages.

Species for which syntheses are available or are in preparation:

American Bittern

Mountain Plover

Marbled Godwit

Long-billed Curlew

Willet

Wilson's Phalarope

Upland Sandpiper

Greater Prairie-Chicken

Lesser Prairie-Chicken

Northern Harrier

Swainson's Hawk

Ferruginous Hawk

Short-eared Owl

Burrowing Owl

Horned Lark

Sedge Wren

Loggerhead Shrike

Sprague's Pipit
Grasshopper Sparrow

Baird's Sparrow

Henslow's Sparrow

Le Conte's Sparrow

Nelson's Sharp-tailed Sparrow

Vesper Sparrow

Savannah Sparrow

Lark Sparrow

Field Sparrow

Clay-colored Sparrow

Chestnut-collared Longspur

McCown's Longspur

Dickcissel

Lark Bunting

Bobolink

Eastern Meadowlark

Western Meadowlark

Brown-headed Cowbird 


\section{EFFECTS OF MANAGEMENT PRACTICES ON GRASSLAND BIRDS:}

\section{FIELD SPARROW}

Jill A. Dechant, Marriah L. Sondreal, Douglas H. Johnson, Lawrence D. Igl, Christopher M. Goldade, Barry D. Parkin, and Betty R. Euliss

Series Coordinator: Douglas H. Johnson

Series Assistant Coordinator: Lawrence D. Igl

Reviewer: Dirk E. Burhans

Range Map: Jeff T. Price

Cover Art: Christopher M. Goldade

Major Funding: Prairie Pothole Joint Venture, U.S. Fish and Wildlife Service U.S. Geological Survey

Funding also provided by: U.S. Forest Service The Nature Conservancy

\section{Collaborators:}

Louis B. Best, Iowa State University

Carl E. Bock, University of Colorado

Brenda C. Dale, Canadian Wildlife Service

Stephen K. Davis, Saskatchewan Wetland Conservation Corporation

James J. Dinsmore, Iowa State University

James K. Herkert, Illinois Endangered Species Protection Board

Fritz L. Knopf, Midcontinent Ecological Science Center

Rolf R. Koford, Iowa Cooperative Fish and Wildlife Research Unit

David R. C. Prescott, Alberta NAWMP Centre

Mark R. Ryan, University of Missouri

David W. Sample, Wisconsin Department of Natural Resources

David A. Swanson, Ohio Division of Wildlife

Peter D. Vickery, Massachusetts Audubon Society

John L. Zimmerman (retired), Kansas State University

May 1999

(revised January 2002) 


\section{ORGANIZATION AND FEATURES OF THIS SPECIES ACCOUNT}

Information on the habitat requirements and effects of habitat management on grassland birds were summarized from information in more than 4,000 published and unpublished papers. A range map is provided to indicate the relative densities of the species in North America, based on Breeding Bird Survey (BBS) data. Although birds frequently are observed outside the breeding range indicated, the maps are intended to show areas where managers might concentrate their attention. It may be ineffectual to manage habitat at a site for a species that rarely occurs in an area. The species account begins with a brief capsule statement, which provides the fundamental components or keys to management for the species. A section on breeding range outlines the current breeding distribution of the species in North America, including areas that could not be mapped using BBS data. The suitable habitat section describes the breeding habitat and occasionally microhabitat characteristics of the species, especially those habitats that occur in the Great Plains. Details on habitat and microhabitat requirements often provide clues to how a species will respond to a particular management practice. A table near the end of the account complements the section on suitable habitat, and lists the specific habitat characteristics for the species by individual studies. A special section on prey habitat is included for those predatory species that have more specific prey requirements. The area requirements section provides details on territory and home range sizes, minimum area requirements, and the effects of patch size, edges, and other landscape and habitat features on abundance and productivity. It may be futile to manage a small block of suitable habitat for a species that has minimum area requirements that are larger than the area being managed. The Brown-headed Cowbird (Molothrus ater) is an obligate brood parasite of many grassland birds. The section on cowbird brood parasitism summarizes rates of cowbird parasitism, host responses to parasitism, and factors that influence parasitism, such as nest concealment and host density. The impact of management depends, in part, upon a species' nesting phenology and biology. The section on breeding-season phenology and site fidelity includes details on spring arrival and fall departure for migratory populations in the Great Plains, peak breeding periods, the tendency to renest after nest failure or success, and the propensity to return to a previous breeding site. The duration and timing of breeding varies among regions and years. Species' response to management summarizes the current knowledge and major findings in the literature on the effects of different management practices on the species. The section on management recommendations complements the previous section and summarizes specific recommendations for habitat management provided in the literature. If management recommendations differ in different portions of the species' breeding range, recommendations are given separately by region. The literature cited contains references to published and unpublished literature on the management effects and habitat requirements of the species. This section is not meant to be a complete bibliography; a searchable, annotated bibliography of published and unpublished papers dealing with habitat needs of grassland birds and their responses to habitat management is posted at the Web site mentioned below.

This report has been downloaded from the Northern Prairie Wildlife Research Center WorldWide Web site, www.npwrc.usgs.gov/resource/literatr/grasbird/grasbird.htm. Please direct comments and suggestions to Douglas H. Johnson, Northern Prairie Wildlife Research Center, U.S. Geological Survey, 8711 37th Street SE, Jamestown, North Dakota 58401; telephone: 701253-5539; fax: 701-253-5553; e-mail: Douglas_H_Johnson@usgs.gov. 


\section{FIELD SPARROW}

(Spizella pusilla)

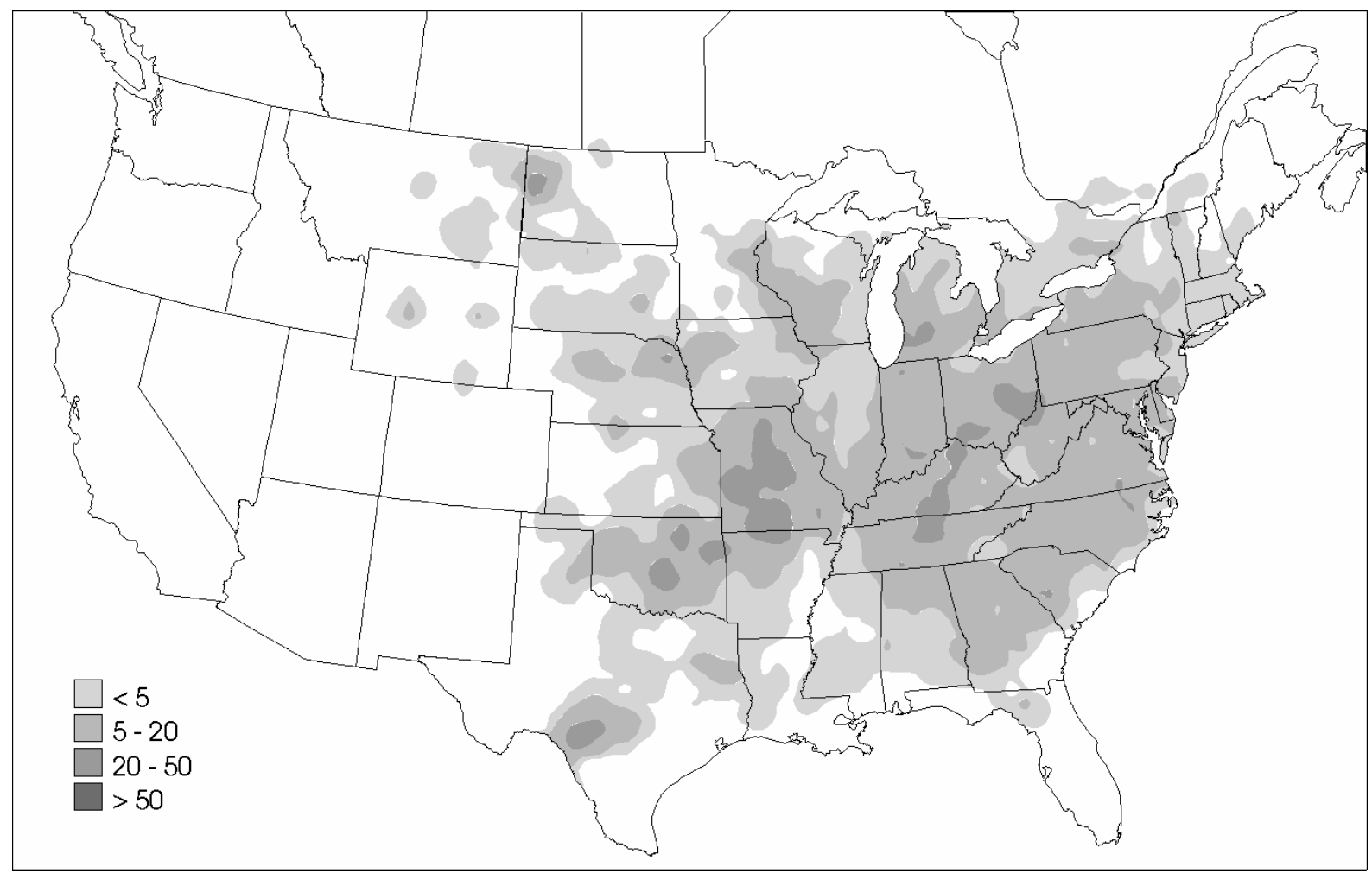

Figure. Breeding distribution of the Field Sparrow in the United States and southern Canada, based on Breeding Bird Survey data, 1985-1991. Scale represents average number of individuals detected per route per year. Map from Price, J., S. Droege, and A. Price. 1995. The summer atlas of North American birds. Academic Press, London, England. 364 pages.

Keys to management include providing shrub-dominated edge habitat adjacent to grassland or providing grassland with a shrub component (both of which must include dense grass and moderately high litter cover), and avoiding disturbances that completely eliminate woody vegetation.

\section{Breeding range:}

Field Sparrows breed from central Montana and Wyoming to eastern North Dakota, south through southcentral Texas to northern Florida, and north to central Minnesota, northern Wisconsin, Michigan, southern Quebec, and Maine (National Geographic Society 1987). (See figure for the relative densities of Field Sparrows in the United States and southern Canada, based on Breeding Bird Survey data.)

\section{Suitable habitat:}

Field Sparrows prefer woody edges and dry to slightly mesic, moderately tall grasslands with moderately abundant litter and a shrub component (Best 1977, 1978; Sousa 1983; Sample 1989; Herkert 1991a). Suitable habitat includes oldfields, sage (Artemisia) flats, weedy pastures, untilled and idle cropland, Conservation Reserve Program fields, grassed waterways, hedgerows, 
shelterbelts, orchards, woodland edges, brushy woodlands, wooded draws, pine (Pinus) plantations, attenuated gallery and gallery forest, and reclaimed strip mines (Gabrielson 1914; Ely 1957; Graber and Graber 1963; Walkinshaw 1968, 1978; Stewart 1975; Best 1977, 1978; Evans 1978; Johnsgard 1980; Stauffer and Best 1980; Whitmore 1980; Best et al. 1981, 1997; Faanes 1981, 1983; Buech 1982; Hopkins 1983; Sousa 1983; Dinsmore et al. 1984; Kahl et al. 1985; Basore et al. 1986; Sample 1989; Bryan and Best 1991; Herkert 1991a; Cable et al. 1992; Zimmerman 1993; Carey et al. 1994; Vickery et al. 1994; Faanes and Lingle 1995).

Woody vegetation and dense grass appear to be critical components for habitat suitability (Johnston 1947, Kupsky 1970, Lanyon 1981, Sousa 1983, Laubach 1984, Herkert 1991a). Percent shrub crown cover, percent of total shrubs $<1.5 \mathrm{~m}$ tall, percent grass canopy cover, and average height of herbaceous canopy were identified as important features of breeding habitat in Sousa's (1983) habitat suitability model. Optimal habitat was described as areas $>2$ ha containing dense, moderately tall grass, low to moderate shrub density with $50-75 \%$ of shrubs $<1.5 \mathrm{~m}$ tall, and shrub cover between $15-35 \%$. Areas where most shrubs were $<1.5 \mathrm{~m}$ in height were considered too sparse in providing adequate numbers of perch sites, whereas areas where most shrubs were $>1.5 \mathrm{~m}$ were considered too sparse in providing adequate numbers of possible nest sites. Areas with $>75 \%$ shrub cover were too dense to be suitable breeding habitat (Sousa 1983). The key to determining suitability of an area for nesting Field Sparrows in Illinois was the availability of shrubs, trees, or other substrates that could be used as song perches; Field Sparrows stayed within or near the forest edge, not venturing deeper than a few meters into the forest, nor farther than 12-15 m into surrounding fields (Johnston 1947). In Illinois, Field Sparrows preferred shrub-grassland, where shrubs and trees were $<8 \mathrm{~m}$ tall, over adjacent grassland or woodland edge; shrub-grassland offered an assemblage of grasses, forbs, trees, and shrubs to accommodate temporal shifts in the nesting and foraging preferences of Field Sparrows (Best 1974a,1977). All available shrub-grassland habitat was encompassed within territories, whereas not all grassland or woodland edge habitat was encompassed within territories. Within riparian habitats ranging from hayfields to closed canopy woodlands in Iowa, Field Sparrow density was positively correlated to species richness of shrubs; $67 \%$ of nine nests were built in shrubs, 22\% in evergreen trees, and 11\% in forbs (Stauffer and Best 1980, Best et al. 1981). Also in Iowa, Field Sparrows preferred grassy areas with shrubs or low trees (Laubach 1984). In Wisconsin, Field Sparrow density was positively correlated with percent woody cover and total number of dead stems (Sample 1989). In North Dakota, Field Sparrows were attracted to wooded draws with a high shrub density (Faanes 1983). In Missouri, grasslands and idle areas occupied by Field Sparrows were characterized by low to intermediate canopy height (2-8 m, never $>8 \mathrm{~m}$ ), few woody stems $<2.5 \mathrm{~cm}$ diameter at breast height (dbh) (approximately 350$700 / \mathrm{ha}$ ), and moderate numbers of woody stems $\geq 2.5 \mathrm{~cm}$ dbh (approximately 25-50/ha) (Kahl et al. 1985).

Moderate amounts of dense grass also are important (Sousa 1983). Optimal grass density is $50-90 \%$ canopy cover, which provides adequate nesting cover, abundant food sources, and ease of movement through vegetation (Sousa 1983). Optimal height of herbaceous vegetation during May and June is $16-32 \mathrm{~cm}$; vegetation with an average height $>40 \mathrm{~cm}$ provides suboptimal habitat and vegetation with an average height $<5 \mathrm{~cm}$ provides inadequate concealment (Sousa 1983). In Wisconsin, Field Sparrows preferred habitats that were relatively undisturbed, that were uncultivated, and that contained an average of $75 \%$ herbaceous cover (Sample 1989). In an Ohio oldfield, Field Sparrows foraged in grasses in higher frequencies 
than expected based on their availability (Kupsky 1970). In Michigan, Field Sparrows preferred to nest in residual stands of Indiangrass (Sorghastrum nutans) over residual stands of big bluestem (Andropogon gerardii) because most of the big bluestem was prostrate whereas most of the Indiangrass was upright (Best 1974a).

Nest height ranges from 0 to $4.4 \mathrm{~m}$ above ground (Walkinshaw 1936, 1945, 1978; Crooks 1948; George 1952; Ely 1957; Nolan 1963; Kupsky 1970; Best 1978; Evans 1978; Lanyon 1981; Buech 1982; Laubach 1984; Carey et al. 1994; D. E. Burhans, North Central Forest Experiment Station, Columbia, Missouri, pers. comm.), but height is dependent upon time of season and substrate type. Field Sparrows nest on or near the ground in weed clumps, grass tufts, or litter early in the breeding season (May-June), but nest in small shrubs and saplings later in the breeding season as vegetative cover increases in height (Walkinshaw 1936, 1945, 1978; Crooks 1948; Crooks and Hendrickson 1953; Nolan 1963; Best 1974a, 1978; Evans 1978; Sousa 1983; Carey et al. 1994). Based on the observations of one male that returned to the same Michigan site for $6 \mathrm{yr}$, May nests were on the ground, and June and July nests averaged $26.0 \mathrm{~cm}$ and 40.5 $\mathrm{cm}$ above the ground, respectively (Walkinshaw 1945). In Iowa, six of 11 nests built in May were above ground with an average height of $16 \mathrm{~cm}$; by June, six of 10 nests were above ground with an average height of $40 \mathrm{~cm}$, and by July, all of the 11 nests found were above ground with an average of $51 \mathrm{~cm}$ (Crooks 1948). It has been surmised that Field Sparrows nest in woody vegetation after foliage becomes dense enough to conceal nests (Crooks 1948, Nolan 1963, Walkinshaw 1978). However, Best (1978) found that Field Sparrows preferred to use residual grasses as a nesting substrate over live grasses or woody vegetation that had leafed out. As long as isolated clumps of residual grass remained exposed from new growth, Field Sparrows nested in residual grass; once residual grass was covered by live grasses, Field Sparrows nested in woody vegetation.

Other habitat features that appear important to Field Sparrows are vegetation patchiness, species richness of herbaceous and woody vegetation, and slope (Stauffer and Best 1980, Best et al.1981, Sample 1989, Vickery et al. 1994). In riparian habitats in Iowa, Field Sparrow densities were positively correlated to horizontal patchiness of shrubs, vertical patchiness of trees, slope, and species richness of grass-like vegetation, shrubs, and evergreen trees; densities were negatively correlated to tree density and tree size, species richness of vines, and vertical stratification of vegetation (Stauffer and Best 1980, Best et al. 1981). In Maine grassland barrens, abundance was positively correlated to habitat patchiness, litter, shrub cover, and short grass, and negatively correlated to bare ground (Vickery 1993, Vickery et al. 1994). Field Sparrow density in Wisconsin was positively correlated to plant species richness (Sample 1989). In Iowa, all 15 breeding territories in an idle pasture were located on semi-wooded hillsides or lowlands (Crooks and Hendrickson 1953). A male Field Sparrow occupied a steep hillside for 6 consecutive years (Walkinshaw 1945). A table near the end of the account lists the specific habitat characteristics for Field Sparrows by study.

\section{Area requirements:}

The habitat suitability model for Field Sparrows posited that breeding habitat should be $>2$ ha (Sousa 1983). However, Kupsky (1970) and Petter et al. (1990) found that Field Sparrows were breeding on fields $<2$ ha. In Illinois, Field Sparrows were encountered on small ( $<10$ ha) sites but were classified as moderately tolerant to habitat fragmentation because they were more frequently encountered on large than on small grassland fragments (Herkert 1991a,b). Field 
Sparrows in this study, however, were more strongly influenced by habitat structure than grassland area, and their absence from some small grassland areas may have been due to a lack of suitable habitat rather than an avoidance of small areas per se (Herkert 1991a; J. R. Herkert, Illinois Endangered Species Protection Board, Springfield, Illinois, pers. comm.). In Maine, Field Sparrow occurrence was not affected by field size (Vickery et al. 1994). Territory sizes range from 0.3 to 2.4 ha (Walkinshaw 1945, 1968, 1978; Crooks 1948; Best 1977; Evans 1978; Laubach 1984). In Illinois, territories that included suboptimal habitats, such as grasslands devoid of woody vegetation and woodlands, were found to be larger in area than those habitats that included only optimal habitat, such as shrubby grassland (Best 1977).

Brown-headed Cowbird brood parasitism:

Brood parasitism of Field Sparrow nests by Brown-headed Cowbirds (Molothrus ater) is common (Friedmann 1963, Friedmann et al. 1977). Parasitism rates vary from $<1 \%$ of 371 nests (M. Carey in Carey et al. 1994) to 80\% of 20 nests (Crooks 1948, Crooks and Henderson 1953). Refer to Table 1 in Shaffer et al. (2003) for rates of cowbird brood parasitism. Field Sparrows may be multiply parasitized (Burhans et al. 2000). Because adult Field Sparrows commonly desert nests due to brood parasitism, they may be poor hosts (Walkinshaw 1949, 1968, 1978; George 1952; Crooks and Hendrickson 1953; Ely 1957; Best 1978; Carey et al. 1994; Burhans 2000; Burhans et al. 2000 ). Of 182 parasitized nests in Michigan, 100 were deserted and only 27 of 234 cowbird eggs hatched (Walkinshaw 1968). In Illinois, 5 of 25 nests were parasitized and 3 of 5 deserted nests also were parasitized (Best 1979). In another Illinois study, 14 of 29 parasitized nests were deserted, compared to none of 21 unparasitized nests (Strausberger and Burhans 2001). In Michigan, only eight of 29 cowbird eggs hatched and, of these, only one cowbird fledgling survived the first week (Crooks 1948). In Missouri, 21 of 47 parasitized nests were deserted; of 54 cowbird eggs in 50 nests, only 4 cowbird chicks fledged from 4 nests (Burhans et al. 2000, Strausberger and Burhans 2001).

For Field Sparrows, no studies have investigated a relationship between patch size and nest success or patch size and rates of brood parasitism by Brown-headed Cowbirds. In an Illinois oldfield surrounded by woodland, six Field Sparrow nests parasitized by Brown-headed Cowbirds were an average of $13.4 \mathrm{~m}$ from the woodland (Best 1978).

Breeding-season phenology and site fidelity:

Field Sparrows arrive on the breeding grounds from about mid-March to early May, and depart late August to early November (Walkinshaw 1936, 1945, 1968, 1978; George 1952; Crooks and Hendrickson 1953; Easterla 1962; Stewart 1975; Best 1977; Evans 1978; Johnsgard 1980; Faanes 1981; Dinsmore et al. 1984; Laubach 1984; Carey et al. 1994). In Michigan, females arrive from late April to early May, about 3 wk later than males arrived (Walkinshaw 1978). Multiple (as many as ten) nest attempts per pair have been reported following failure of previous nesting attempts (Walkinshaw 1945, 1978; George 1952; Best 1974b; Evans 1978; Carey et al. 1994). There are known cases of Field Sparrows double- and triple-brooding (Walkinshaw 1945, George 1952, Evans 1978, Carey et al. 1994). In Pennsylvania, 30\% of 160 females successfully fledged two broods, and 1\% successfully fledged three broods (Carey et al. 1994). Fidelity to breeding sites does occur; in only one documented case has a banded fledgling returned and bred at the natal site (Walkinshaw 1945, 1978; George 1952; Best 1977, 1979; Carey et al. 1994). In Michigan, Walkinshaw (1978) reported instances of pairs mating 
for two successive years. Walkinshaw (1945) also documented that one male returned to the same breeding territory for six consecutive summers.

\section{Species' response to management:}

Complete removal of woody vegetation from an area may make it unattractive to Field Sparrows (Stauffer and Best 1980, Sousa 1983). In Illinois, Field Sparrows appeared tolerant to burning in shrub-grassland if woody vegetation remained and burning occurred after territories had been established (Best 1979). Field Sparrows moved from the adjacent burned tallgrass and woodland edge into the shrub-grassland. Burning also caused a decrease in parasitism rates and nest desertion resulting from parasitism. Also in Illinois, Field Sparrows preferred burned areas 3-4 yr postburn but were not present $\geq 5$ yr postburn (Westemeier and Buhnerkempe 1983; Herkert 1991a, 1994a). In Iowa, one nest was found just $27 \mathrm{~d}$ after the area was burned (Laubach 1984). In Wisconsin, Field Sparrow density was positively correlated with the proportion of plots that was burned (Sample 1989). In Kansas tallgrass prairie, Field Sparrows did not occur in annually burned watersheds, probably because they lacked woody vegetation (Zimmerman 1993). In the same study area, Field Sparrows occurred in prairie that was neither burned or grazed, but were absent from ungrazed prairie that was annually burned (Zimmerman 1997). In Nebraska, Field Sparrow abundance did not differ between pastures grazed by cattle and a pasture grazed by American bison (Bison bison), or between burned and unburned areas in the pasture grazed by American bison (Griebel et al. 1998). In Maine, Field Sparrows avoided grassland barrens $\geq 3$ yr postburn (Vickery 1993). In Michigan, following a burn in early spring, only males that had bred on the burned area the previous year bred on the burned area

(Walkinshaw 1945). Some males whose territories were severely burned did not acquire a mate until the vegetation had recovered. One male did not acquire a mate until July but still was able to successfully nest.

In Illinois, Field Sparrows selected idle areas over areas that were high-mowed (stubble $>30 \mathrm{~cm}$ remains on the field), and were absent in hayed areas (Westemeier and Buhnerkempe 1983). However, in another Illinois study, Field Sparrows were absent from both tame hayfields and idle fields (Herkert 1991a). In Iowa, Field Sparrows nested only in grassed waterways that were mowed the previous year (Bryan and Best 1994). Also in Iowa, they nested in low densities in strip cover, such as grassed waterways, terraces, fencerows, and road rights-of-way (Basore et al. 1986). They also nested in soybean fields that were not tilled in fall and spring and that contained year-round crop residue; they did not nest in spring-tilled fields. In Illinois, Field Sparrows were observed more frequently in a corn field under no-tillage treatment than in a conventionally tilled corn field, possibly because there was greater availability of invertebrates in the former corn field (Warburton and Klimstra 1984). In a study of avian use of cropland in Ohio, Field Sparrows used fallow cropland, pasture, and small grains grown in strips between idle cropland (Good and Dambach 1943). In Wisconsin, Field Sparrows were absent from hayfields and cropland (Sample 1989). In New York, Field Sparrows avoided fields mowed annually and nested in oldfields 2-16 yr following the cessation of cultivation; after that time the fields were no longer attractive, probably due to lack of suitable nesting cover such as weeds and saplings (Lanyon 1981). McCoy et al. (1999) reported that fecundity of Field Sparrows over 3 yr in Missouri CRP fields was high enough to maintain a stable population.

Little information exists concerning the effects of pesticides on Field Sparrows. In New York, carbaryl was sprayed on shrubs at normal levels and at levels six times the normal dose 
(Bart 1979). Field Sparrows were not affected by the spraying; the number of singing male Field Sparrows did not significantly differ between the treated areas and the control areas. In New York, Field Sparrows did not breed for 18 yr in a field where vegetation was removed by a onetime application of 2,4,5-T and kerosene (Lanyon 1981). In Texas, in a study examining the effects on avian density of discing, spraying of 2,4,5-T approximately $14 \mathrm{yr}$ earlier, and construction of brush shelters, grassland sparrows, as a group, were more abundant in the treated than untreated areas; effects on particular species, such as Field Sparrow, composing the group of grassland sparrows, were not examined (Gruver and Guthery 1986). In a study examining the effects of DDT dust for tick (Amblyomma americanum) control in Texas, numbers of nesting Field Sparrows decreased in the treated area (George and Stickel 1949).

\section{Management Recommendations:}

Avoid management practices that completely remove woody vegetation (Best 1979, Stauffer and Best 1980).

Protect existing prairie remnants (Herkert 1994b). Collaborate with private landowners to maintain habitat suitable for breeding Field Sparrows (Herkert 1994b).

Manipulations of forested riparian habitats that benefit Field Sparrows include reducing woody vegetation to narrow strips, partially removing woody canopy, and thinning shrubs and saplings (Stauffer and Best 1980).

Disturbance, such as burning, should be avoided before territories have been established, approximately March to early April (Best 1979, Carey et al. 1994, Herkert 1994b). Burning after territories already have been established does not appear to cause Field Sparrows to abandon their territories (Best 1979, Carey et al. 1994).

Burning should be used to prevent encroachment of woody vegetation, but some woody vegetation should be allowed to remain (Best 1979, Carey et al. 1994, Herkert 1994b).

On prairie fragments $>80$ ha, burning should be conducted on a rotating schedule with $20-30 \%$ of area treated annually (Herkert 1994a). Small, isolated prairie fragments should not have more than $50-60 \%$ of total area burned at a time, and where several small prairie fragments are present, a rotating schedule also can be implemented to provide adjacent burned and unburned areas (Herkert 1994a).

In Iowa, mowing should be delayed until late August or early September to prevent destruction of nests and young; however, mowing should not occur later than mid-September, as vegetation will not have time to recover before the winter and following spring (Bryan and Best 1991).

Minimize tillage, because conventional tillage leaves little or no crop residue on the soil surface. Reduced tillage allows $15-30 \%$ of crop residue to remain, whereas conservation tillage allows $\geq 30 \%$ of crop residue to remain (Basore et al. 1986, Koford and Best 1996). 
Table. Field Sparrow habitat characteristics.

\begin{tabular}{|c|c|c|c|}
\hline Author(s) & Location(s) & Habitat(s) Studied* & Species-specific Habitat Characteristics \\
\hline Bart 1979 & New York & Idle & $\begin{array}{l}\text { Abundance did not significantly differ among control areas, } \\
\text { areas treated with normal doses of carbaryl (1-naphthyl } \\
\text { methylcarbamate), and areas treated with doses six times above } \\
\text { normal }\end{array}$ \\
\hline Basore et al. 1986 & Iowa & Cropland, idle & $\begin{array}{l}\text { Nested in strip cover (fencerows, road rights-of-way, terraces, } \\
\text { and waterways) and untilled fields where soybeans were planted } \\
\text { into corn residue; did not nest in tilled fields or untilled fields } \\
\text { where corn was planted into sod or corn was planted into corn } \\
\text { residue }\end{array}$ \\
\hline $\begin{array}{l}\text { Best 1974a, 1977, } \\
1978\end{array}$ & Illinois & $\begin{array}{l}\text { Idle, idle seeded-native, } \\
\text { woodland, woodland } \\
\text { edge }\end{array}$ & $\begin{array}{l}\text { Preferred to nest in standing litter in shrub-grassland early in the } \\
\text { season and in trees and shrubs later in the season; average nest } \\
\text { heights ranged from } 30 \mathrm{~cm} \text { above ground for nests in grasses, } 36 \\
\mathrm{~cm} \text { for those in forbs, and } 45 \mathrm{~cm} \text { for those in trees and shrubs; } \\
\text { territories were never confined solely to grassland or shrub- } \\
\text { woodland; preferred to nest in upright, residual Indiangrass } \\
\text { (Sorghastrum nutans) over prostrate, residual big bluestem } \\
\text { (Andropogon gerardii) }\end{array}$ \\
\hline Best 1979 & Illinois & $\begin{array}{l}\text { Burned idle, burned } \\
\text { seeded-native, burned } \\
\text { woodland edge, idle, idle } \\
\text { seeded-native, woodland, } \\
\text { woodland edge }\end{array}$ & $\begin{array}{l}\text { Appeared to tolerate burning in shrub-grassland if woody } \\
\text { vegetation remains and burning occurs after territories have } \\
\text { been established; nest parasitism and nest desertion caused } \\
\text { largely by parasitism both declined after burning }\end{array}$ \\
\hline
\end{tabular}




\begin{tabular}{|c|c|c|c|}
\hline $\begin{array}{l}\text { Bryan and Best } \\
1994\end{array}$ & Iowa & $\begin{array}{l}\text { Cropland, idle tame, } \\
\text { tame hayland }\end{array}$ & Nested only in waterways that were hayed the previous year \\
\hline Buech 1982 & Minnesota & Conifer plantation & $\begin{array}{l}\text { Nested in Scotch pine (Pinus sylvestris) plantation; average } \\
\text { height of nest tree was } 142 \mathrm{~cm} \text { and average nest height was } 44 \\
\mathrm{~cm}\end{array}$ \\
\hline Carey et al. 1994 & Rangewide & $\begin{array}{l}\text { Idle, woodland, } \\
\text { woodland edge }\end{array}$ & $\begin{array}{l}\text { Used areas with scattered woody vegetation such as oldfields, } \\
\text { road rights-of-way, railroad rights-of-way, and woodland edges; } \\
\text { early nests were on the ground in grass clumps or at the base of } \\
\text { shrubs, and later nests were in shrubs and small trees }\end{array}$ \\
\hline $\begin{array}{l}\text { Crooks 1948, } \\
\text { Crooks and } \\
\text { Hendrickson } 1953\end{array}$ & Iowa & $\begin{array}{l}\text { Idle tame pasture, tame } \\
\text { pasture }\end{array}$ & $\begin{array}{l}\text { Nested in weed clumps or small shrubs on partially wooded } \\
\text { hillsides but never on ridgetops; number of nests built on the } \\
\text { ground decreased as the height of vegetative cover increased; in } \\
\text { May, six of } 11 \text { nests were built above ground in hawthorn } \\
\text { (Crataegus) shrubs, and average height was } 16 \mathrm{~cm} \text {; in June, six } \\
\text { of } 10 \text { nests were built above ground in hawthorn shrubs, and } \\
\text { average height was } 40 \mathrm{~cm} \text {; in July, all of } 11 \text { nests were in shrubs } \\
\text { (mostly hawthorn), and average nest height was } 51 \mathrm{~cm} \text { above } \\
\text { ground; May nests that were on the ground were in forb clumps } \\
\text { such as gromwell (Lithospermum latifolium), European } \\
\text { gromwell (Lithospermum officinale), and rigid goldenrod } \\
\text { (Solidago rigida); three of the June nests were in gromwell } \\
\text { clumps and one was in a dense tangle of Kentucky bluegrass } \\
\text { (Poa pratensis) and wild buckwheat (Polygonum convolvulus) }\end{array}$ \\
\hline $\begin{array}{l}\text { Dinsmore et al. } \\
1984\end{array}$ & Iowa & $\begin{array}{l}\text { Idle, pasture, woodland } \\
\text { edge }\end{array}$ & $\begin{array}{l}\text { Nested in idle fields, pastures containing shrubs, and woodland } \\
\text { edges }\end{array}$ \\
\hline Ely 1957 & Oklahoma & Idle, tame pasture, & Used edges of willow (Salix) groves and oldfields; nested in \\
\hline
\end{tabular}




\begin{tabular}{|c|c|c|c|}
\hline & & $\begin{array}{l}\text { woodland, woodland } \\
\text { edge }\end{array}$ & $\begin{array}{l}\text { juniper (Juniperus), persimmon (Diospyros virginiana), winged } \\
\text { elm (Ulmus alata), and greenbrier (Smilax bona-nox); nest } \\
\text { heights ranged from about } 60 \text { to } 90 \mathrm{~cm} \text {; the only successful nest } \\
\text { was in juniper }\end{array}$ \\
\hline Evans 1978 & Michigan & Idle & $\begin{array}{l}\text { Nested on the ground, in herbaceous cover }(5-25 \mathrm{~cm} \text { above } \\
\text { ground), in small trees }(5-90 \mathrm{~cm}) \text {, and in dwarf juniper } \\
\text { (Juniperus communis) }(7-90 \mathrm{~cm}) \text {; preferred nesting in juniper; } \\
\text { nest success in junipers was significantly higher than in other } \\
\text { substrates, but nests in junipers were parasitized by Brown- } \\
\text { headed Cowbirds (Molothrus ater) at a slightly higher rate }\end{array}$ \\
\hline Faanes 1981 & $\begin{array}{l}\text { Minnesota, } \\
\text { Wisconsin }\end{array}$ & $\begin{array}{l}\text { Conifer plantation, } \\
\text { cropland, idle, idle } \\
\text { tallgrass/tame, tame } \\
\text { hayland, wetland, wet } \\
\text { meadow, woodland }\end{array}$ & $\begin{array}{l}\text { Nested in oldfields, idle fields, young pine (Pinus) plantations, } \\
\text { and brushy forest openings }\end{array}$ \\
\hline Faanes 1983 & North Dakota & $\begin{array}{l}\text { Idle mixed-grass, mixed- } \\
\text { grass pasture }\end{array}$ & $\begin{array}{l}\text { Occurred in wooded draws with high shrub density and low } \\
\text { percent canopy cover }\end{array}$ \\
\hline $\begin{array}{l}\text { Faanes and Lingle } \\
1995\end{array}$ & Nebraska & $\begin{array}{l}\text { Cropland, idle mixed- } \\
\text { grass, idle shortgrass, } \\
\text { idle tallgrass, pasture, } \\
\text { sand-sage grassland, } \\
\text { tame hayland, wetland, } \\
\text { wet meadow, woodland }\end{array}$ & $\begin{array}{l}\text { Nested in upland prairie, lowland forest, and river channel } \\
\text { islands; found most often on the edge of native grassland that } \\
\text { was being invaded by Rocky Mountain juniper (Juniperus } \\
\text { scopulorum) and that contained an abundance of soapweed } \\
\text { yucca (Yucca glauca); also used shrubby thickets, field edges, } \\
\text { and extensive growths of willow saplings on river channel } \\
\text { islands }\end{array}$ \\
\hline George 1952 & Michigan & $\begin{array}{l}\text { Cropland, hayland, } \\
\text { pasture, woodland edge }\end{array}$ & $\begin{array}{l}\text { Placed territories along forest edge; usually nested on the } \\
\text { ground or within } 75 \mathrm{~cm} \text { of the ground }\end{array}$ \\
\hline Good and Dambach & Ohio & Cropland, idle, pasture & Were observed in idle cropland, pasture, and small grain grown \\
\hline
\end{tabular}




\begin{tabular}{|c|c|c|c|}
\hline 1943 & & & in strips between strips of idle cropland \\
\hline $\begin{array}{l}\text { Graber and Graber } \\
1963\end{array}$ & Illinois & $\begin{array}{l}\text { Cropland, hayland, idle, } \\
\text { idle grassland, tame } \\
\text { pasture, wetland, } \\
\text { woodland }\end{array}$ & Used shrubs, hedgerows, orchards, and pastures \\
\hline Herkert $1991 a$ & Illinois & $\begin{array}{l}\text { Burned seeded-native, } \\
\text { burned tallgrass, } \\
\text { cropland, idle seeded- } \\
\text { native, idle tallgrass, idle } \\
\text { tame, tame hayland }\end{array}$ & $\begin{array}{l}\text { Were most abundant on large and small prairie fragments three } \\
\text { growing seasons ( }>25 \text { months) postburn, and were absent from } \\
\text { tame grass areas, both hayed and idle; were moderately tolerant } \\
\text { to fragmentation. Univariate analysis: density was significantly } \\
\text { and positively correlated with average number of live grass } \\
\text { contacts, average number of live forb contacts, and woody stem } \\
\text { density } / \mathrm{m}^{2} \text {; density was significantly and negatively correlated } \\
\text { with average grass height, total number of contacts of grass, } \\
\text { forb, and dead vegetation, and area. Multivariate analysis: } \\
\text { density was significantly and positively correlated with shrub } \\
\text { and forb abundance, and significantly and negatively correlated } \\
\text { with total vegetation richness and live plant richness }\end{array}$ \\
\hline Herkert $1991 b$ & Illinois & $\begin{array}{l}\text { Idle seeded-native, idle } \\
\text { tallgrass, idle tame }\end{array}$ & Were present on tallgrass prairie fragments $<10$ ha \\
\hline Herkert $1994 a$ & Illinois & $\begin{array}{l}\text { Burned seeded-native, } \\
\text { burned tallgrass }\end{array}$ & $\begin{array}{l}\text { Were most abundant three growing seasons ( }>25 \text { months) } \\
\text { postburn; abundance was negatively associated with area }\end{array}$ \\
\hline Herkert $1994 b$ & Illinois & $\begin{array}{l}\text { Idle seeded-native, idle } \\
\text { tallgrass, idle tame }\end{array}$ & $\begin{array}{l}\text { Positive predictor of occurrence was mean vegetation height; } \\
\text { negative predictor of occurrence was mean grass height; } \\
\text { occurrence was unaffected by field size }\end{array}$ \\
\hline Johnsgard 1980 & Nebraska & $\begin{array}{l}\text { Idle, idle hayland, idle } \\
\text { mixed-grass, idle } \\
\text { shortgrass, idle tallgrass, } \\
\text { mixed-grass pasture, }\end{array}$ & $\begin{array}{l}\text { Were found in brushy woodlands, forest edges, brushy ravines, } \\
\text { idle hayfields, forest clearings, and similar open habitats having } \\
\text { scattered shrubs or low trees }\end{array}$ \\
\hline
\end{tabular}




\begin{tabular}{|c|c|c|c|}
\hline & & $\begin{array}{l}\text { tallgrass pasture, } \\
\text { woodland, woodland } \\
\text { edge }\end{array}$ & \\
\hline Johnston 1947 & Illinois & $\begin{array}{l}\text { Hayland, woodland, } \\
\text { woodland edge }\end{array}$ & $\begin{array}{l}\text { Used woodland edge; were not found deep in woodland or }>12- \\
15 \text { m into surrounding hayfields; important factor in habitat } \\
\text { suitability was availability of shrubs, trees, or fences used as } \\
\text { song perches }\end{array}$ \\
\hline Kahl et al. 1985 & Missouri & $\begin{array}{l}\text { Burned tallgrass, } \\
\text { cropland, idle, idle } \\
\text { tallgrass, tallgrass } \\
\text { hayland, tallgrass } \\
\text { pasture, woodland, } \\
\text { woodland edge }\end{array}$ & $\begin{array}{l}\text { Used oldfields and grassland areas with low to moderate canopy } \\
\text { height }(2-8 \mathrm{~m}) \text {, dense ground vegetation, few woody stems }<2.5 \\
\mathrm{~cm} \text { diameter at breast height (dbh), and a moderate number of } \\
\text { woody stems } \geq 2.5 \mathrm{~cm} \text { dbh }\end{array}$ \\
\hline Kupsky 1970 & Ohio & Idle & $\begin{array}{l}\text { Nested in hawthorn, saplings, berry (Rubus spp.) clumps, and on } \\
\text { the ground; nests were }<25 \mathrm{~cm} \text { from the ground and were } \\
\text { partially concealed by dead vegetation }\end{array}$ \\
\hline Lanyon 1981 & New York & Hayland, idle & $\begin{array}{l}\text { Nested in shrubs at an average height of } 20 \mathrm{~cm} \text {, and in } \\
\text { herbaceous vegetation at an average height of } 18 \mathrm{~cm} \text { tall; also } \\
\text { nested on the ground; used oldfields } 2-16 \mathrm{yr} \text { after cultivation } \\
\text { ceased; avoided areas mowed annually }\end{array}$ \\
\hline Laubach 1984 & Iowa & $\begin{array}{l}\text { Burned tallgrass, idle } \\
\text { tallgrass }\end{array}$ & $\begin{array}{l}\text { Preferred a combination of grassy areas with shrubs or low } \\
\text { trees; nested in tall forbs such as rosin-weed (Silphium } \\
\text { integrifolium) and in wild plum (Prunus americana); nest } \\
\text { heights were as high as } 1 \mathrm{~m} \text {; one nest was found in a recently } \\
\text { burned area }\end{array}$ \\
\hline McCoy et al. 1999 & Missouri & $\begin{array}{l}\text { CRP (idle seeded-native, } \\
\text { idle tame) }\end{array}$ & $\begin{array}{l}\text { Fecundity over } 3 \text { yr within CRP fields was high enough to } \\
\text { support a stable population }\end{array}$ \\
\hline
\end{tabular}




\begin{tabular}{|c|c|c|c|}
\hline Nolan 1963 & Indiana & $\begin{array}{l}\text { Idle, woodland, } \\
\text { woodland edge }\end{array}$ & $\begin{array}{l}\text { Of } 21 \text { nests initiated in May, } 17 \text { were placed on the ground; on } \\
23 \text { May, the first elevated nest was built; by } 3 \text { June, all nests } \\
\text { were elevated; } 48 \text { plant species were used as nesting substrates, } \\
\text { and the three most commonly used plant species for nesting } \\
\text { were American elm (Ulmus americanus), blackberry (Rubus), } \\
\text { and hawthorn; elevated nests heights ranged from } 0.15 \text { to } 3 \mathrm{~m} \text {, } \\
\text { with an average of } 1 \mathrm{~m}\end{array}$ \\
\hline Sample 1989 & Wisconsin & $\begin{array}{l}\text { Burned tallgrass, } \\
\text { cropland, DNC (idle } \\
\text { seeded-native, idle } \\
\text { tame), idle, idle seeded- } \\
\text { native, idle tallgrass, idle } \\
\text { tallgrass/tame, idle tame, } \\
\text { tame hayland, tame } \\
\text { pasture, tame savanna } \\
\text { pasture, wet meadow, } \\
\text { wet-meadow pasture }\end{array}$ & $\begin{array}{l}\text { Preferred dry to slightly mesic, brushy areas that were } \\
\text { undisturbed or uncultivated; used areas characterized by an } \\
\text { average of } 75 \% \text { herbaceous cover, } 18 \% \text { litter cover, } 7 \% \text { bare } \\
\text { ground, } 72 \mathrm{~cm} \text { maximum vegetation height, and } 20 \mathrm{~cm} \\
\text { vegetation height/density; density was positively correlated with } \\
\text { percent woody cover, total number of dead stems, proportion of } \\
\text { burned plots, and number of plant species }\end{array}$ \\
\hline Sousa 1983 & Rangewide & $\begin{array}{l}\text { Idle, woodland, } \\
\text { woodland edge }\end{array}$ & $\begin{array}{l}\text { Habitat suitability model posited that Field Sparrows used areas } \\
>2 \text { ha that contained dense ( } 50-90 \% \text { of canopy cover), } \\
\text { moderately tall grass, low to moderate shrub density with } 50- \\
75 \% \text { of shrubs }<1.5 \mathrm{~m} \text { tall, and shrub cover between } 15-35 \% \text {; } \\
\text { areas where all shrubs were }<1.5 \text { m were considered sparse in } \\
\text { numbers of perch sites, whereas areas with all shrubs }>1.5 \mathrm{~m} \\
\text { were considered sparse in numbers of possible nest sites; areas } \\
\text { with }>75 \% \text { shrub cover were too dense; optimal height of } \\
\text { herbaceous vegetation during May and June was } 16-32 \mathrm{~cm} \text {; } \\
\text { average herbaceous vegetation heights }>40 \text { cm provided } \\
\text { suboptimal habitat and heights }<5 \text { cm provided inadequate } \\
\text { concealment }\end{array}$ \\
\hline Stauffer and Best & & Hayland, idle, pasture, & Nested in shrubs, coniferous trees, and forbs; density was \\
\hline
\end{tabular}




\begin{tabular}{|c|c|c|c|}
\hline $\begin{array}{l}1980, \\
\text { Best et al. } 1981\end{array}$ & Iowa & $\begin{array}{l}\text { woodland, woodland } \\
\text { edge }\end{array}$ & $\begin{array}{l}\text { positively associated with horizontally patchy shrubs, vertically } \\
\text { patchy trees, slope, and species richness of grass-like vegetation, } \\
\text { shrubs, and evergreen trees; density was negatively associated } \\
\text { with tree density and tree size }\end{array}$ \\
\hline Stewart 1975 & North Dakota & $\begin{array}{l}\text { Idle mixed-grass, } \\
\text { woodland }\end{array}$ & $\begin{array}{l}\text { Nested in mixed-grass prairie containing silver sagebrush } \\
\text { (Artemisia cana), brushy draws, woodlands, and thickets }\end{array}$ \\
\hline $\begin{array}{l}\text { Vickery 1993, } \\
\text { Vickery et al. } 1994\end{array}$ & Maine & $\begin{array}{l}\text { Eastern grassland barren: } \\
\text { burned, mowed, and/or } \\
\text { sprayed with herbicides }\end{array}$ & $\begin{array}{l}\text { Avoided grasslands } \geq 3 \text { yr postburn; density was positively } \\
\text { correlated with litter, shrub cover, short grass, area, and habitat } \\
\text { patchiness; density was negatively correlated with area and bare } \\
\text { ground }\end{array}$ \\
\hline $\begin{array}{l}\text { Walkinshaw 1936, } \\
1968\end{array}$ & Michigan & Idle & $\begin{array}{l}\text { Built early nests on the ground; later nests were built in small } \\
\text { shrubs and tree saplings and ranged from } 5 \text { to } 120 \mathrm{~cm} \text { above the } \\
\text { ground; most nests were } 15 \text { to } 30 \mathrm{~cm} \text { above ground }\end{array}$ \\
\hline Walkinshaw 1945 & Michigan & Idle & $\begin{array}{l}\text { Based on one male that returned to the same area for six } \\
\text { summers, } 15 \text { nests were found; May nests were built on the } \\
\text { ground underneath tufts of dead grass; June nests averaged } 26 \\
\text { cm above ground, and July nests averaged } 40.5 \mathrm{~cm} \text {; eight of the } \\
\text { above-ground nests were in New Jersey tea bushes (Ceanothus } \\
\text { americanus) ranging in height from } 24 \text { to } 48 \mathrm{~cm} \text { and two nests } \\
\text { were in small bitternut hickory (Carya cordiformis) trees } 11 \text { and } \\
23 \mathrm{~cm} \text { above ground }\end{array}$ \\
\hline Walkinshaw 1978 & Michigan & Idle & $\begin{array}{l}\text { In May, nests were built on the ground under clumps of Carolina } \\
\text { crabgrass (Digitaria cognata var. cognata); from June to } \\
\text { August, nests were found in New Jersey tea bushes, hawthorn } \\
\text { (Crataegus sp.), blackberry (Rubus spp.), and small oaks } \\
\text { (Quercus spp.); mean height of nests in June was } 21 \mathrm{~cm} \text {; mean } \\
\text { height of nests in both July and August was } 31 \mathrm{~cm}\end{array}$ \\
\hline Westemeier and & & Burned tallgrass, idle & Preferred burned areas 3-4 yr postburn, were absent $\geq 5 \mathrm{yr}$ \\
\hline
\end{tabular}




\begin{tabular}{|l|l|l|l|}
\hline Buhnerkempe 1983 & Illinois & $\begin{array}{l}\text { seeded-native, tallgrass } \\
\text { hayland }\end{array}$ & $\begin{array}{l}\text { postburn; selected idle areas over high-mowed (leaves stubble } \\
30-50 \mathrm{~cm} \text { high) areas; did not occur in hayed areas }\end{array}$ \\
\hline
\end{tabular}

*In an effort to standardize terminology among studies, various descriptors were used to denote the management or type of habitat. "Idle" used as a modifier (e.g., idle tallgrass) denotes undisturbed or unmanaged (e.g., not burned, mowed, or grazed) areas. "Idle” by itself denotes unmanaged areas in which the plant species were not mentioned. Examples of "idle” habitats include weedy or fallow areas (e.g., oldfields), fencerows, grassed waterways, terraces, ditches, and road rights-of-way. "Tame" denotes introduced plant species (e.g., smooth brome [Bromus inermis]) that are not native to North American prairies. "Hayland" refers to any habitat that was mowed, regardless of whether the resulting cut vegetation was removed. "Burned” includes habitats that were burned intentionally or accidentally or those burned by natural forces (e.g., lightning). In situations where there are two or more descriptors (e.g., idle tame hayland), the first

descriptor modifies the following descriptors. For example, idle tame hayland is habitat that is usually mowed annually but happened to be undisturbed during the year of the study. 


\section{LITERATURE CITED}

Bart, J. 1979. Effects of acephate and Sevin on forest birds. Journal of Wildlife Management 43:544-549.

Basore, N. S., L. B. Best, and J. B. Wooley. 1986. Bird nesting in Iowa no-tillage and tilled cropland. Journal of Wildlife Management 50:19-28.

Best, L. B. 1974a. Breeding ecology of the Field Sparrow (Spizella pusilla). Ph.D. dissertation. University of Illinois, Urbana, Illinois. 163 pages.

Best, L. B. 1974b. An unusual case of nesting persistence in a female Field Sparrow. Condor 76:349.

Best, L. B. 1977. Territory quality and mating success in the Field Sparrow (Spizella pusilla). Condor 79:192-204.

Best, L. B. 1978. Field Sparrow reproductive success and nesting ecology. Auk 95:9-22.

Best, L. B. 1979. Effects of fire on a Field Sparrow population. American Midland Naturalist 101:434-443.

Best, L. B., H. Campa, III, K. E. Kemp, R. J. Robel, M. R. Ryan, J. A. Savidge, H. P. Weeks, Jr., and S. R. Winterstein. 1997. Bird abundance and nesting in CRP fields and cropland in the Midwest: a regional approach. Wildlife Society Bulletin 25:864-877.

Best, L. B., D. F. Stauffer, A. R. Geier, K. L. Varland, J. P. Vogler, R. B. Dahlgren, and R. Q. Landers. 1981. Effects of habitat alterations on riparian plant and animal communities in Iowa. U.S. Department of the Interior, Fish and Wildlife Service, FWS/OBS-81/26. 55 pages.

Bryan, G. G., and L. B. Best. 1991. Bird abundance and species richness in grassed waterways in Iowa rowcrop fields. American Midland Naturalist 126:90-102.

Bryan, G. G., and L. B. Best. 1994. Avian nest density and success in grassed waterways in Iowa rowcrop fields. Wildlife Society Bulletin 22:583-592.

Buech, R. R. 1982. Nesting ecology and cowbird parasitism of Clay-colored, Chipping and Field sparrows in a Christmas tree plantation. Journal of Field Ornithology 53:363-369.

Burhans, D. E. 2000. Morning nest arrivals in cowbird hosts: their role in aggression, cowbird recognition, and host response to parasitism. Pages 161-168 in J. N. M. Smith, T. L. Cook, S. I. Rothstein, S. K. Robinson, and S. G. Sealy, editors. Ecology and management of cowbirds and their hosts. University of Austin Press, Austin, Texas.

Burhans, D. E., F. R. Thompson, III, and J. Faaborg. 2000. Costs of parasitism incurred by two songbird species and their quality as cowbird hosts. Condor 102:364-373. 
Cable, T. T., R. L. Schroeder, V. Brack, Jr., and P. S. Cook. 1992. Summer bird use of Kansas windbreaks. Prairie Naturalist 24:175-184.

Carey, M., D. E. Burhans, and D. A. Nelson. 1994. Field Sparrow (Spizella pusilla). In A. Poole and F. Gill, editors. The birds of North America, No. 103. The Academy of Natural Sciences, Philadelphia, Pennsylvania; The American Ornithologists’ Union, Washington, D.C.

Crooks, M. P. 1948. Life history of the Field Sparrow, Spizella pusilla pusilla (Wilson). M.S. thesis. Iowa State College, Ames, Iowa. 109 pages.

Crooks, M. P., and G. O. Hendrickson. 1953. Field Sparrow life history in central Iowa. Iowa Bird Life 23:10-13.

Dinsmore, J. J., T. H. Kent, D. Koenig, P. C. Peterson, and D. M. Roosa. 1984. Iowa birds. Iowa State University Press, Ames, Iowa. 356 pages.

Easterla, D. A. 1962. Avifauna of Tucker Prairie. M.A. thesis. University of Missouri, Columbia, Missouri. 144 pages.

Ely, C. A. 1957. Comparative nesting success on certain south-central Oklahoma birds. M.S. thesis. University of Oklahoma, Norman, Oklahoma. 74 pages.

Evans, E. W. 1978. Nesting responses of Field Sparrows (Spizella pusilla) to plant succession on a Michigan old field. Condor 80:34-40.

Faanes, C. A. 1981. Birds of the St. Croix River Valley: Minnesota and Wisconsin. U.S. Fish and Wildlife Service, North American Fauna 73. 196 pages.

Faanes, C. 1983. Breeding birds of wooded draws in western North Dakota. Prairie Naturalist 15:173-187.

Faanes, C. A., and G. R. Lingle. 1995. Breeding birds of the Platte River Valley of Nebraska. Jamestown, ND: Northern Prairie Wildlife Research Center home page. http://www.npwrc.usgs.gov/resource/distr/birds/platte/platte.htm (Version 16JUL97).

Friedmann, H. 1963. Host relations of the parasitic cowbirds. U.S. National Museum Bulletin 233:1-276.

Friedmann, H., L. F. Kiff, and S. I. Rothstein. 1977. A further contribution to knowledge of the host relations of the parasitic cowbirds. Smithsonian Contributions to Zoology 235:1-75.

Gabrielson, I. N. 1914. Ten days’ bird study in a Nebraska swamp. Wilson Bulletin 26:51-68.

George, J. L. 1952. The birds on a southern Michigan farm. Ph.D. dissertation. University of Michigan, Ann Arbor, Michigan. 413 pages. 
George, J. L., and W. H. Stickel. 1949. Wildlife effects of DDT dust used for tick control on a Texas prairie. American Midland Naturalist 42:228-237.

Good, E. E., and C. A. Dambach. 1943. Effect of land use practices on breeding bird populations in Ohio. Journal of Wildlife Management 7:291-297.

Graber, R. R., and J. W. Graber. 1963. A comparative study of bird populations in Illinois, 1906-1909 and 1956-1958. Illinois Natural History Survey Bulletin 28:383-528.

Griebel, R. L., S. L. Winter, and A. A. Steuter. 1998. Grassland birds and habitat structure in sandhills prairie management using cattle or bison plus fire. Great Plains Research 8:255-268.

Gruver, B. J., and F. S. Guthery. 1986. Effects of brush control and game-bird management on nongame birds. Journal of Range Management 39:251-253.

Herkert, J. R. 1991a. An ecological study of the breeding birds of grassland habitats within Illinois. Ph.D. dissertation. University of Illinois, Urbana, Illinois. 112 pages.

Herkert, J. R. 1991b. Study suggests increases in restored prairie fragments to conserve breeding bird communities. Restoration and Management Notes 9:107.

Herkert, J. R. 1994a. Breeding bird communities of midwestern prairie fragments: the effects of prescribed burning and habitat-area. Natural Areas Journal 14:128-135.

Herkert, J. R. 1994b. The effects of habitat fragmentation on midwestern grassland bird communities. Ecological Applications 4:461-471.

Hopkins, R. 1983. Vegetation structure and avian communities in some rangeland types of western North Dakota. Proceedings of the North Dakota Academy of Science 37:82.

Johnsgard, P. A. 1980. A preliminary list of the birds of Nebraska and adjacent Plains states. University of Nebraska, Lincoln, Nebraska. 156 pages.

Johnston, V. R. 1947. Breeding birds of the forest edge in Illinois. Condor 49:45-53.

Kahl, R. B., T. S. Baskett, J. A. Ellis, and J. N. Burroughs. 1985. Characteristics of summer habitats of selected nongame birds in Missouri. Research Bulletin 1056. University of Missouri, Columbia, Missouri. 155 pages.

Koford, R. R., and L. B. Best. 1996. Management of agricultural landscapes for the conservation of Neotropical migratory birds. Pages 68-88 in F. R. Thompson, III, editor. Management of midwestern landscapes for the conservation of Neotropical migratory birds. U.S. Forest Service General Technical Report NC-187.

Kupsky, E. 1970. Habitat utilization and invertebrate exploitation in the Field Sparrow, Spizella pusilla. M.S. thesis. Ohio State University, Columbus, Ohio. 65 pages. 
Lanyon, W. E. 1981. Breeding birds and old field succession on fallow Long Island farmland. Bulletin of the American Museum of Natural History. Volume 168. 60 pages.

Laubach, R. 1984. Breeding birds of Sheeder Prairie Preserve, west-central Iowa. Proceedings of the Iowa Academy of Science 91:153-163.

McCoy, T. D., M. R. Ryan, E. W. Kurzejeski, and L. W. Burger, Jr. 1999. Conservation reserve program: source or sink habitat for grassland birds in Missouri? Journal of Wildlife Management 63:530-538.

National Geographic Society. 1987. Field guide to the birds of North America, second edition. National Geographic Society, Washington, D.C. 464 pages.

Nolan, V., Jr. 1963. Reproductive success of birds in a deciduous scrub habitat. Ecology 44:305-313.

Petter, S. C., D. B. Miles, and M. M. White. 1990. Genetic evidence of mixed reproductive strategy in a monogamous bird. Condor 92:702-708.

Sample, D. W. 1989. Grassland birds in southern Wisconsin: habitat preference, population trends, and response to land use changes. M.S. thesis. University of Wisconsin, Madison, Wisconsin. 588 pages.

Shaffer, J. A., C. M. Goldade, M. F. Dinkins, D. H. Johnson, L. D. Igl, and B. R. Euliss. 2003. Brown-headed Cowbirds in grasslands: their habitats, hosts, and response to management. Prairie Naturalist 35:146-186.

Sousa, P. J. 1983. Habitat suitability index models: Field Sparrow. FWS/OBS-82/10.62. U.S. Fish and Wildlife Service. 14 pages.

Stauffer, D. F., and L. B. Best. 1980. Habitat selection by birds of riparian communities: evaluating effects of habitat alterations. Journal of Wildlife Management 44:1-15.

Stewart, R. E. 1975. Breeding birds of North Dakota. Tri-College Center for Environmental Studies, Fargo, North Dakota. 295 pages.

Strausberger, B. M., and D. E. Burhans. 2001. Nest desertion by Field Sparrows and its possible influence on the evolution of cowbird behavior. Auk 118:770-776.

Vickery, P. D. 1993. Habitat selection of grassland birds in Maine. Ph.D. dissertation. University of Maine, Orono, Maine. 124 pages.

Vickery, P. D., M. L. Hunter, and S. M. Melvin. 1994. Effects of habitat area on the distribution of grassland birds in Maine. Conservation Biology 8:1087-1097.

Walkinshaw, L. H. 1936. Notes on the Field Sparrow in Michigan. Wilson Bulletin 48:94-101.

Walkinshaw, L. H. 1945. Field Sparrow, 39-54015. Bird-Banding 16:1-14. 
Walkinshaw, L. H. 1949. Twenty-five eggs apparently laid by a cowbird. Wilson Bulletin 61:82-85.

Walkinshaw, L. H. 1968. Eastern Field Sparrow. Pages 1217-1235 in O. L. Austin, editor. Life histories of North American cardinals, grosbeaks, buntings, towhees, finches, sparrows, and allies. Dover Publications, Inc., New York, New York.

Walkinshaw, L. H. 1978. Life history of the eastern Field Sparrow in Calhoun County, Michigan. University Microfilm International, Ann Arbor, Michigan. 153 pages.

Warburton, D. B., and W. D. Klimstra. 1984. Wildlife use of no-tilled and conventional tilled corn fields. Journal of Soil and Water Conservation 39:327-330.

Westemeier, R. L., and J. E. Buhnerkempe. 1983. Responses of nesting wildlife to prairie grass management in prairie chicken sanctuaries in Illinois. Pages 36-46 in R. Brewer, editor. Proceedings of the Eighth North American Prairie Conference. Western Michigan University, Kalamazoo, Michigan.

Whitmore, R. C. 1980. Reclaimed surface mines as avian habitat islands in the eastern forest. American Birds 34:13-14.

Zimmerman, J. L. 1993. Birds of Konza: the avian ecology of the tallgrass prairie. University of Kansas Press, Lawrence, Kansas. 186 pages.

Zimmerman, J. L. 1997. Avian community responses to fire, grazing, and drought in the tallgrass prairie. Pages 167-180 in F. L. Knopf and F. B. Samson, editors. Ecology and conservation of Great Plains vertebrates. Springer-Verlag, New York, New York. 